\title{
Socioeconomic position and childhood- adolescent weight status in rich countries: a systematic review, 1990-2013
}

\author{
Laura Barriuso ${ }^{1}$, Estrella Miqueleiz ${ }^{2 *}$, Romana Albaladejo ${ }^{3}$, Rosa Villanueva ${ }^{3}$, Juana M. Santos ${ }^{3,4}$ \\ and Enrique Regidor $3,4,5$
}

\begin{abstract}
Background: Childhood obesity is a major problem in rich countries due to its high prevalence and its harmful health consequences. An exploratory analysis conducted in the PubMed database highlighted that the number of papers published on the relationship between socioeconomic position (SEP) and childhood-adolescent weight status had risen substantially with respect to an earlier review which had covered the period 1990-2005.

Methods: To describe the findings on the relationship between SEP and childhood-adolescent weight status in papers published in rich countries from 1990 through 2013, studies were identified in the following databases: PubMed; Web of Knowledge (WOK); PsycINFO; Global Health; and Embase. We included observational studies from the 27 richest OECD countries, which covered study populations aged 0 to 21 years, and used parental education, income and/or occupation as family SEP indicators. A total of 158 papers met the inclusion criteria and reported 134 bivariable and 90 multivariable analyses.

Results: Examination of the results yielded by the bivariable analyses showed that $60.4 \%$ of studies found an inverse relationship, $18.7 \%$ of studies did not found relationship, and $20.9 \%$ of studies found a relationship that varied depending on another variable, such as age, sex or ethnic group; the corresponding percentages in the multivariable analyses were 51.1, 20.0 and $27.8 \%$, respectively. Furthermore, $1.1 \%$ found a positive relationship.

Conclusion: The relationship between SEP and childhood-adolescent weight status in rich countries is predominantly inverse and the positive relationship almost has disappeared. The SEP indicator that yields the highest proportion of inverse relationships is parents' education. The proportion of inverse relationships is higher when the weight status is reported by parents instead using objective measurements.
\end{abstract}

Keywords: Childhood obesity, Socioeconomic position, Systematic review, Rich countries

\section{Background}

In rich countries, childhood obesity is a public health problem of the first order due to its high prevalence and short- and long-term health repercussions [1-5]. Childhood obesity is not only an important risk factor for childhood/adolescent diseases, such as diabetes mellitus, sleep apnea, asthma, precocious puberty and psychological disorders [5-7], but because a high percentage of obese children become obese adults. Among the factors

\footnotetext{
*Correspondence: emikeleiz@yahoo.es

${ }^{2}$ Department of Sociology, Universidad Pública de Navarra, Campus de Arrosadía, s/n, 31006 Pamplona, Spain

Full list of author information is available at the end of the article
}

that increase the likelihood of childhood obesity are the social determinants such as the SEP [8].

The relationship between SEP and body weight was already suggested in the latter part of the $19^{\text {th }}$ century. In 1889, Veblen considered that slimness was an ideal of feminine beauty, indicative of the social status pertaining to the emerging leisure social class of the age [9]. Several decades had to elapse before the relationship between SEP and weight status came to be examined. Indeed, it was a century later, in 1989, when Sobal and Stunkard published an extensive bibliographic review on the influence exerted by SEP on obesity among children and adults in developed and developing countries [10]. They 
analyzed a total of 144 studies published in the preceding 40 years and concluded that the relationship varied according to subject's age and sex, and countries' degree of development. In developed countries, they observed a clear inverse relationship between SEP and obesity in women -in that the highest and lowest proportions of obesity were observed in women of low and high SEP, respectively- and an inconsistent relationship in men, boys and girls. For example, 35 papers published between 1941 and 1986 made reference to the relationship between SEP and obesity in children and adolescents. In boys an inverse relationship was observed in $32 \%$ of studies, a positive relationship -the highest and lowest proportions of obesity in high and low SEP, respectively- in $26 \%$ and an absence of relationship in $41 \%$; in girls an inverse relationship was observed in $40 \%$ of studies, a positive relationship in 25 $\%$ s and an absence of relationship in $35 \%$. In developing countries, however, an intense positive relationship was observed in women, men, boys and girls.

In 2008, Shrewsbury and Wardle published another systematic review focusing exclusively on the relationship between SEP and childhood adiposity in developed countries [11]. It included 45 studies, published from January 1990 through December 2005, which had been conducted on populations aged 5 to 18 years, using family and neighborhood SEP indicators. Again, the relationship found was inconsistent $-42 \%$ inverse relationship, $27 \%$ absence of relationship, $31 \%$ inconclusive- Only one positive relationship between PES and obesity, in girls in an adjusted analysis, was observed. A comparison with the results of the previous review highlighted a change in the pattern of this relationship, i.e., while studies reporting a positive relationship had disappeared, the percentage of studies displaying an inverse relationship had risen.

Faced with the prospect of new findings, an exploratory bibliographic search was made in The National Library of Medicine's PubMed to bring the situation up to date, and revealed a sharp rise in scientific activity in this area from 2005. Hence, the idea of updating the systematic review and extending it to other databases was deemed to be of interest. An increase in the percentage of studies whose results show an inverse relationship would support intervention strategies that seek to reduce childhood obesity, directing the focus to the lower socioeconomic groups. Specifically, the aim of this study was to report the findings of a systematic review of epidemiologic evidence of the association between family SEP and weight status in the child-adolescent population in high income countries, across the period 1990-2013.

\section{Methods}

The dependent variable used for the purposes of this systematic review was childhood-adolescent weight status, measured either by reference to the presence of excess weight (overweight and/or obesity) or some anthropometric parameter. To identify potentially relevant publications, we conducted a bibliographic search in available databases having the greatest scientific impact on the medical and social fields. Accordingly, the following five databases were analyzed: The National Library of Medicine's PubMed; Web of Knowledge (WoK); PsycINFO; Global Health; and Excerpta Medica Database (Embase). In the selection of the search strategy we follow the recommendations of Pettigrew and Roberts [12]. Because we used multiple bibliographic databases and the studies in some databases do not have structured abstract and keywords, we decided to use the search terms as major topics in each database, in order that the search be more comprehensive to identify all relevant studies. Previously we got a sample of studies from each database that met the inclusion criteria we discuss below. In this way we get to find out the major topics terms that were used in each database to search for potential relevant articles. The main characteristics of the search strategy used are shown in Table 1.

The inclusion criteria of the papers were: a) published from January 1, 1990 through December 31, 2013; b) in English or Spanish; c) study participants having an age range of 0 to 21 years; d) observational studies; e) use of parental education, income, and/or occupation as the family SEP indicator; and, f) conducted in a "high income country", defined as any of members of the Organization for Economic Cooperation and Development (OECD) having a gross domestic product per head (US \$, current PPPs) higher than 25,000 dollars, according to the International Monetary Fund's figures for 2010. These countries were Australia, Austria, Belgium, Canada, Czech Republic, Denmark, Finland, France, Germany, Greece, Holland, Iceland, Ireland, Israel, Italy, Japan, Korea, Luxembourg, New Zealand, Norway, Portugal, Slovenia, Spain, Sweden, Switzerland, United Kingdom and the USA.

The exclusion criteria ruled out any paper that: a) reported an intervention study; b) used race-ethnic group as a SEP indicator; or c) only included area-level SEP index. We decided to exclude the SEP of the area due to the heterogeneity of the level of aggregation of the areas -sections census, districts, provinces, regions, countries-, in these studies, the variety of area-level SEP index and the variety of measures of individual SEP used by researchers in these studies to control for residual confounding of the association between area-level SEP index and health outcome [13].

\section{Methods Data extraction and quality assessment}

Potentially relevant papers were selected by screening the titles, abstract and the entire articles through the 
Table 1 Bibliographic search strategy

\begin{tabular}{|c|c|}
\hline Database & Search terms \\
\hline PubMed & $\begin{array}{l}\text { ("Obesity" (MeSH Major Topic) OR "overweight" (MeSH Major Topic) OR "adiposity" } \\
\text { (MeSH Major Topic) OR "body mass index" (MeSH Major Topic)) AND ("social class" } \\
\text { (MeSH Major Topic) OR "occupations" (MeSH Major Topic) OR "employment" } \\
\text { (MeSH Major Topic)). }\end{array}$ \\
\hline Web of Knowledge (WoK) & Topic "Childhood obesity" AND Topic "social class". \\
\hline PsycINFO & $\begin{array}{l}\text { 1. (Socioeconomic and Status and Adiposity and Childhood).mp. [mp = title, abstract, } \\
\text { heading word, table of contents, key concepts]; } 2 \text {. socioeconomic status/ or "income } \\
\text { (economic)"/ or poverty/; 3. from } 1 \text { keep } 1-8 ; 4 \text {. body fat/ or body weight/; } 5 \text {. exp } \\
\text { Obesity/ or obesity.mp.; } 6 \text {. Adiposity.mp.; } 7 \text {. Childhood.mp.; } 8 \text {. children.mp.; } 9.4 \text { or } 5 \text { or } \\
\text { 6; } 10.7 \text { or } 8 ; 11.2 \text { and } 9 \text { and } 10 ; 12 \text {. Socioeconomic and Status and Adiposity and } \\
\text { Childhood; } 13 \text {. limit } 12 \text { to (100 childhood and five stars and last } 20 \text { years); } 14 \text {. from } \\
11 \text { keep } 1-90 \text {. }\end{array}$ \\
\hline Global Health & $\begin{array}{l}\text { 1. Socioeconomic and Status and Adiposity and Childhood; } 2 \text {. limit } 1 \text { to last } 24 \text { years; } \\
\text { 3. exp obesity/; } 4 \text {. socioeconomic status/ or social status/ or economic sociology/ } \\
\text { or living conditions/; } 5 \text {. children/; 6. Childhood.mp.; } 7.5 \text { or } 6 ; 8.3 \text { and } 4 \text { and } 7 .\end{array}$ \\
\hline Embase & $\begin{array}{l}\text { 1. Socioeconomic and Status and Adiposity and Childhood; } 2 \text {. (Socioeconomic and } \\
\text { Status and Adiposity and Childhood).mp. [mp = title, abstract, subject headings, heading } \\
\text { word, drug trade name, original title, device manufacturer, drug manufacturer]; 3. social } \\
\text { status/; } 4 \text {. from } 3 \text { keep 1-27; } 5 \text {. obesity/di, ep, et, pc, si [Diagnosis, Epidemiology, Etiology, } \\
\text { Prevention, Side Effect]; } 6 \text {. child/; } 7.3 \text { and } 5 \text { and } 6 \text {. }\end{array}$ \\
\hline
\end{tabular}

database searches. Two authors (LB and JMS) independently conducted this screening. Disagreement about eligibility between the reviewers was solved through discussion with a third author (ER). Two authors (LB and EM) extracted the data from the included studies using a pilot data extraction form. Data relating to sample size, sex and age of study subjects, date of the study, weight status outcomes (objectively measured, parentreport, cut-off points), familiar socioeconomic position and findings by familiar socioeconomic position were extracted.

All studies were quality assessed by one author (RA) and checked by another (RV). Since there are a variety of checklist and scales to evaluate the quality of observational studies and they differ by content, format, validity and applicability to different studies $[14,15]$, none of the proposed instruments was used. In any case, each study was assessed using the following item: clear definition of the objective and the study population, justification of the sample size and representativeness of the same, clear definition of the independent and dependent variables, measuring variables in all study subjects or absence of information from these variables in a proportion of subjects and assessment of potential confounders in multivariate analysis. Also, we followed PRISMA guidelines to report the systematic review.

\section{Data analysis}

We have not performed formal meta-analysis as the necessary conditions of comparability of exposures, together with homogeneity of association direction and strength [16], are not met. Results are presented as a narrative synthesis. This paper reports the results of bivariable and multivariable analyses. Whereas the bivariable analyses show the results for the SEP/weight status relationship obtained on the basis of crude analyses or analyses adjusted for age and/or sex, the multivariable analyses show the results of analyses that included other variables of adjustment. Results were classified into "inverse relationship", "positive relationship" or "absence of relationship". A relationship was defined as "inverse" when the measure of weight status displayed the highest and lowest magnitudes in participants of low and high SEP, respectively, and in addition, when there was a statistically significant difference between them, and/or the $p$-value for linear trend across the different SEP categories was statistically significant. A relationship was defined as "positive" when the measure of weight status displayed the lowest and highest magnitudes in participants of low and high SEP, respectively, and in addition, when there was a statistically significant difference between them, and/or the $p$-value for linear trend across the different SEP categories was statistically significant. In all cases, a $p$-value of less than 0.05 was taken as the criterion of statistical significance. An "absence of relationship" was deemed to exist when there was no statistically significant relationship between the indicator of weight status and SEP. In any case when a paper reported different results in different population groups analyzed, in different study periods, or according to the type of dependent variable analyzed, this was described as a relationship that "varies depending on another variable". In order to render the presentation of the findings as uniform as possible, we calculated the odds ratios in those cases in which the articles only showed frequency measures, either by taking the highest 
SEP category as reference, or alternatively by reestimating the measure of association shown if the reference category used was the lowest SEP. In cases where papers showed no results tables, we included those that the authors cited literally in the text.

\section{Results}

The electronic search produced 6215 references. After removing duplicate references titles and abstract were screened. One thousand and one hundred twenty fulltext outputs were assessed; 158 outputs were included and 962 were excluded (Fig. 1):671 because they did not meet some of the inclusion criteria, 29 because they were intervention studies, 204 because they used raceethnic and 58 because they only used area-level SEP index. The 158 papers that fulfilled the inclusion criteria are shown in Additional file 1: Table S1. The studies came from the following countries: 48 from the USA [17-64]; 22 from the United Kingdom [65-86]; 18 from Germany [87-104]; 11 from Australia [105-115]; eight from France [116-123]; seven from Spain [124-130]; six from Canada [131-136]; five from Sweden [137-141], Greece [142-146] and Holland [147-151]; four from Belgium [152-155] and Italy [156-159]; two from Finland [160, 161], Portugal [162, 163], Denmark [164, $165]$ and Ireland [166, 167]; one from several countries [168] and one each from the Czech Republic [169],
Iceland [170], Israel [171], Korea [172], Norway [173] and Switzerland [174].

The studies analyzed samples of boys and girls, except in three cases in which only girls were included [41, 48, 57]. Sample size varied widely, ranging from 77 to 90,808 participants. All the studies analyzed participants aged 0 to 21 years, except one in which the age range was 2 to 24 years: this was nonetheless included in our review because it did not present the data broken down by age [126]. Twenty one studies examined individuals of a single age $[20,42,51,65,69,70,72,73,80,88,106,131,132$, 137-140, 149, 154, 166, 170]. Four cases [25-27, 134] did not mention the individuals" ages but referred instead to their current school grade. In three instances, papers reported the same results but, seeing as the authors' objectives were different $[46,60,61]$, they were analyzed separately.

Table 2 shows the number of papers according to period of publication, region of origin, SEP indicator, method for collecting anthropometric data, and criterion used for defining weight status. The earliest paper analyzed had been published in 1992 [82], and over half of the papers appeared in the period 2006-2013. All were published in English, except two which were published in Spanish [126, 130]. Just over half the papers came from Europe and one third from North America. While $28.5 \%$ of the papers used the father's and/or mother's

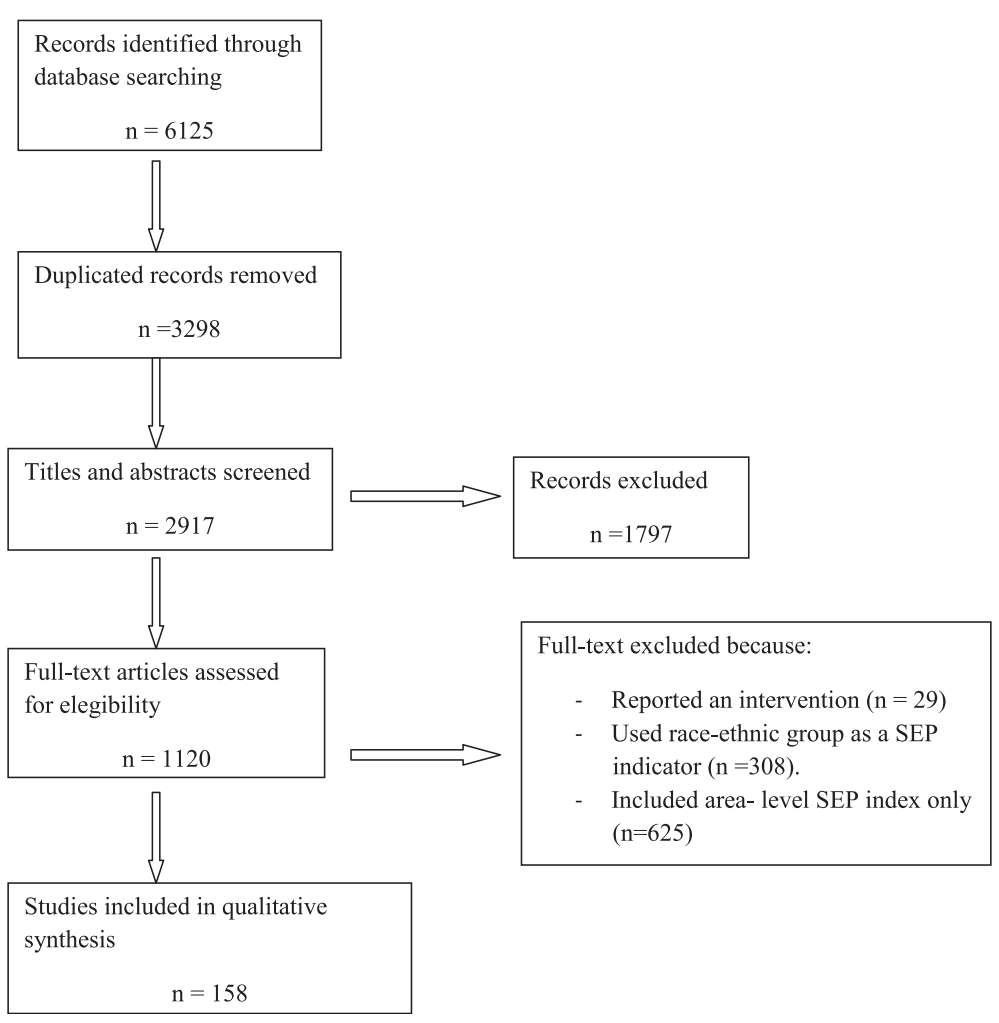

Fig. 1 PRISMA flow diagram 
Table 2 Number of papers found on the relationship between family socioeconomic position and weight status in the child-adolescent population, according to different classification criteria: period 1990-2013

\begin{tabular}{|c|c|c|}
\hline Total & $\begin{array}{l}\text { Number } \\
158\end{array}$ & $\begin{array}{l}\text { Percent } \\
100\end{array}$ \\
\hline \multicolumn{3}{|l|}{ Period of publication } \\
\hline 1990-1997 & 7 & 4.4 \\
\hline 1998-2005 & 58 & 36.7 \\
\hline $2006-2013$ & 93 & 58.9 \\
\hline \multicolumn{3}{|l|}{ Region } \\
\hline North America & 54 & 34.2 \\
\hline Europe & 91 & 57.6 \\
\hline Remaining countries $^{b}$ & 13 & 8.2 \\
\hline \multicolumn{3}{|l|}{ Indicator of socioeconomic position } \\
\hline Family income & 10 & 6.3 \\
\hline Mother's and/or father's education & 45 & 28.5 \\
\hline Mother's and/or father's occupation & 27 & 17.1 \\
\hline Various indicators & 76 & 48.1 \\
\hline \multicolumn{3}{|c|}{ Method for collecting anthropometric data } \\
\hline Measured & 124 & 78.5 \\
\hline Reported & 32 & 20.3 \\
\hline Both & 1 & 0.6 \\
\hline No data & 1 & 0.6 \\
\hline \multicolumn{3}{|l|}{ Criterion for defining weight status } \\
\hline IOTF $^{a}$ cut-off pointy & 58 & 36.7 \\
\hline CDC cut-off points & 32 & 20.3 \\
\hline WHO cut-off pints & 4 & 2.5 \\
\hline Other/s criteria/s & 64 & 40.5 \\
\hline
\end{tabular}

aOTF: International Obesity Task Force

${ }^{\mathrm{b}}$ Remaining countries included Australia, Israel and Korea

education as the SEP indicator, nearly half the papers used various SEP indicators. The measurement of weight most frequently used was Body Mass Index (BMI), with weight and height being measured by the researchers themselves in $78.5 \%$ of the papers. In $63.3 \%$ of papers the references used for the definition of excess weight were tables or cut-off points of a national or supranational nature. In $37 \%$ of the studies it was used internationally accepted cut-off points defined by the International Obesity Task Force (IOTF) [175], and from 2001 onwards, almost half the papers published used this definition of excess weight. In $20 \%$ of the studies it was used the CDC cut-off points, although most of these studies come from USA.

In terms of type of analysis, 68 studies solely performed bivariable analyses, 66 performed bivariable and multivariable analyses, and 24 solely performed multivariable analyses. In all, the papers reviewed provided
134 bivariable and 90 multivariable analyses. Diverse multivariable models were used, in terms both of the number (from two to more than 10) and types of variables of adjustment contained. These variables mainly referred to study participants' ethnicity or birth weight, various behaviours (breastfeeding, physical activity, sedentarism, consumption of some type of food), parents' BMI, mother's characteristics (smoking, age, civil status, depressive symptoms linked to pregnancy) and characteristics of the area of residence (facilities, rurality).

The bivariable analyses showed the presence of an inverse relationship between family SEP and weight status in $60.4 \%$ of cases, an absence of relationship in $18.7 \%$ of cases and a relationship that varied when according to another variable (generally age, sex, ethnicity) in $20.9 \%$ of cases. The multivariable analyses showed an inverse relationship in $51.1 \%$, an absence of relationship in $20.7 \%$, a changing relationship according to the breakdown variable in $27.8 \%$, and a positive relationship in $1.1 \%$ of cases. In some papers, the magnitude of the inverse relationship between SEP and the weight-status indicator was higher for girls than for boys [40, 60, 122, 124, 173]. Similarly, there were 17 studies in which the magnitude of the inverse relationship was greater with obesity than with overweight $[61,64,87-91,97,99,101$, $102,120,121,135,149,150,159]$ and was likewise greater with severe overweight than with overweight [171] and with morbid obesity than with obesity [47] among the four studies that examined both measures of overweight or obesity [47, 153, 154, 171]. Among the studies in which the relationship varied depending on another variable, mention should be made of some that displayed an inverse relationship in girls but no relationship in boys [30-32, 44, 85, 137, 147, 154], others that displayed an inverse relationship in boys and no relationship in girls $[40,125,174]$, and still others that displayed an inverse relationship in white but not in African American participants [30, 31, 41, 50, 57, 65].

Table 3 shows the results for the type of relationship found between family SEP and childhood-adolescent weight status, according to the studies' period of publication and region of origin. Until 1997 a consistent inverse relationship between socioeconomic status and childhood obesity was not observed. On the basis of the bivariable analyses, the percentage of papers reporting an inverse relationship was $0 \%$ in the period 1990$1997,62.3 \%$ in the period $1998-2005$, and $64.0 \%$ in the period 2006-2013, while the corresponding percentages in the case of the multivariable analyses were $0,53.6$ and $54.4 \%$, respectively. When viewed by region of origin, the bivariable analyses showed around $60.0 \%$ of papers reported an inverse relationship in all regions; in the multivariable analyses, these percentages were 58.8, 51.1 
Table 3 Type of relationship observed in the papers according to period of publication and region of origin

\begin{tabular}{|c|c|c|c|c|}
\hline \multirow[t]{2}{*}{ Type of relationship } & \multicolumn{2}{|c|}{$\begin{array}{l}\text { Bivariate analysis } \\
\text { (n: 134) }\end{array}$} & \multicolumn{2}{|c|}{$\begin{array}{l}\text { Multivariate analysis } \\
\text { (n: 90) }\end{array}$} \\
\hline & $n$ & $\%$ & $n$ & $\%$ \\
\hline \multicolumn{5}{|l|}{ PERIOD OF PUBLICATION } \\
\hline 1990-1997 & 6 & 100.0 & 5 & 100.0 \\
\hline Inverse relationship & 0 & 0.0 & 0 & 0.0 \\
\hline Absence of relationship & 2 & 33.3 & 2 & 40.0 \\
\hline $\begin{array}{l}\text { Varies depending on } \\
\text { another variable }\end{array}$ & 4 & 66.7 & 3 & 60.0 \\
\hline 1998-2005 & 53 & 100.0 & 28 & 100.0 \\
\hline Inverse relationship & 33 & 62.3 & 15 & 53.6 \\
\hline Absence of relationship & 10 & 18.9 & 5 & 17.9 \\
\hline $\begin{array}{l}\text { Varies depending on } \\
\text { another variable }\end{array}$ & 10 & 18.9 & 7 & 25.0 \\
\hline Direct relationship & 0 & 0.0 & 1 & 3.6 \\
\hline $2006-2013$ & 75 & 100.0 & 57 & 100.0 \\
\hline Inverse relationship & 48 & 64.0 & 31 & 54.4 \\
\hline Absence of relationship & 13 & 17.3 & 11 & 19.3 \\
\hline $\begin{array}{l}\text { Varies depending on } \\
\text { another variable }\end{array}$ & 14 & 18.7 & 15 & 26.3 \\
\hline \multicolumn{5}{|l|}{ REGION } \\
\hline North America & 44 & 100.0 & 34 & 100.0 \\
\hline Inverse relationship & 27 & 61.4 & 20 & 58.8 \\
\hline Absence of relationship & 4 & 9.1 & 5 & 14.7 \\
\hline $\begin{array}{l}\text { Varies depending on } \\
\text { another variable }\end{array}$ & 13 & 29.5 & 9 & 26.5 \\
\hline Europe & 77 & 100.0 & 47 & 100.0 \\
\hline Inverse relationship & 46 & 59.7 & 24 & 51.1 \\
\hline Absence of relationship & 18 & 23.4 & 9 & 19.1 \\
\hline $\begin{array}{l}\text { Varies depending on } \\
\text { another variable }\end{array}$ & 13 & 16.9 & 13 & 27.7 \\
\hline Direct relationship & 0 & 0.0 & 1 & 2.1 \\
\hline Other ${ }^{a}$ & 13 & 100.0 & 9 & 100.0 \\
\hline Inverse relationship & 8 & 61.5 & 2 & 22.2 \\
\hline Absence of relationship & 3 & 23.1 & 4 & 44.4 \\
\hline $\begin{array}{l}\text { Varies depending on } \\
\text { another variable }\end{array}$ & 2 & 15.4 & 3 & 33.3 \\
\hline
\end{tabular}

${ }^{\mathrm{a}}$ Remaining countries

and $22.2 \%$ in North America, Europe and other regions, respectively.

One of the main findings in this review is the heterogeneity of age groups analyzed in the included studies. Therefore it is not possible to show the relationship between socioeconomic position and childhood obesity -and / or the magnitude in specific age groups. The exception is the few studies in children under five years, since in some of them the multivariate analysis showed no relationship between maternal education with childhood obesity [114, 132, 139].

Table 4 shows the results for the type of relationship found between family SEP and weight status, according to the SEP indicator and weight-status definition used. The number of analyses carried out with income was small. In the bivariable analyses an inverse relationship was observed in $37.5 \%$ of studies that used family income, in $65.8 \%$ of studies that used the father's and/or mother's education, and in $41.7 \%$ of studies that used the father's and/or mother's occupation. In the multivariable analyses, the corresponding percentages were 75.0, 62.5 and $41.7 \%$, respectively. In general, when the education of the mother and father's education were analyzed, the magnitude of the association was stronger with the education of the mother. For example, in two studies [97, 104] the magnitude of the odds ratios of obesity in the category with lower levels of education with respect to the category with the highest educational level was, respectively, 5.26 and 4.38 with the mother's education and 4.58 and 2.22 with the father's education. With some exception, the higher magnitude of the association was observed with income in those studies that analyzed the family income and other measures of income socioeconomic status $[19,33,57,58,61,62,122$, $131,136]$. Specifically, in these studies, the odds ratio for overweight and obesity in the category of lower family income with respect to the category of higher family incomes ranged between 1.52 [19] and 2.91 [58].

When measurements of weight and height were conducted by researchers an inverse relationship was observed in $54.1 \%$ of studies. However, when weight status was derived from self-reported height and weight, an inverse relationship was observed in $87.0 \%$ of studies. In studies in which overweight and obesity were analyzed separately, the magnitude of the association was higher with obesity. For example, the odds ratios in the category with lower education with respect the category with higher parental education in different studies were 1.89 and 2.08 [102], 1.49 and 1.92 [99], 1.43 and 2.10 [86], 1.17 and 2.10 [89], 1.57 and 4.39 [97], 2.16 and 4.10 [149], and 1.42 and 2.82 [150] for overweight and obesity, respectively. One study estimated the magnitude of the association with weight and height measured by researches and weight and height reported by the research subjects [121]. The odds ratio in the children of manual workers with regard to the children of professionals and managers was 1.50 for overweight and 2.67 for obesity when weight and height were measured and 1.36 and 3.67 , respectively, when weight and height were selfreported.

In the studies that used the IOFT cut- off points to define weight status, an inverse relationship was found in $66.0 \%$ of the bivariable analyses and in $44.4 \%$ of the 
Table 4 Type of relationship observed in papers according to socioeconomic position indicator, outcome's values and criterion used for defining weight status

\begin{tabular}{|c|c|c|c|c|}
\hline \multirow[t]{2}{*}{ Type of relationship } & \multicolumn{2}{|c|}{ Bivariate analysis (n: 134) } & \multicolumn{2}{|c|}{ Multivariate analysis (n: 90) } \\
\hline & $\bar{n}$ & $\%$ & $\mathrm{n}$ & $\%$ \\
\hline \multicolumn{5}{|l|}{ INDICATOR OF SOCIOECONOMIC POSITION } \\
\hline Family income & 8 & 100.0 & 4 & 100.0 \\
\hline Inverse relationship & 3 & 37.5 & 3 & 75.0 \\
\hline Absence of relationship & 2 & 25.0 & 1 & 25.0 \\
\hline Varies depending on another variable & 3 & 37.5 & 0 & 0.0 \\
\hline Mother's and/or father's education & 38 & 100.0 & 24 & 100.0 \\
\hline Inverse relationship & 25 & 65.8 & 15 & 62.5 \\
\hline Absence of relationship & 7 & 18.4 & 4 & 16.7 \\
\hline Varies depending on another variable & 6 & 15.8 & 5 & 20.8 \\
\hline Mother's and/or father's occupation & 24 & 100.0 & 12 & 100.0 \\
\hline Inverse relationship & 10 & 41.7 & 5 & 41.7 \\
\hline Absence of relationship & 9 & 37.5 & 5 & 41.7 \\
\hline Varies depending on another variable & 5 & 20.8 & 2 & 16.7 \\
\hline Various indicators $^{\mathrm{a}}$ & 64 & 100.0 & 50 & 100.0 \\
\hline Inverse relationship & 43 & 67.2 & 23 & 46.0 \\
\hline Absence of relationship & 7 & 10.9 & 8 & 16.0 \\
\hline Varies depending on another variable & 14 & 21.9 & 18 & 36.0 \\
\hline Direct & 0 & 0.0 & 1 & 2.0 \\
\hline \multicolumn{5}{|c|}{ METHOD FOR COLLECTING ANTHROPOMETRIC DATA } \\
\hline Measured & 109 & 100.0 & 64 & 100.0 \\
\hline Inverse relationship & 59 & 54.1 & 29 & 45.3 \\
\hline Absence of relationship & 24 & 22.0 & 13 & 20.3 \\
\hline Varies depending on another variable & 26 & 23.9 & 21 & 32.8 \\
\hline Direct & 0 & 0.0 & 1 & 1.6 \\
\hline Reported & 23 & 100.0 & 24 & 100.0 \\
\hline Inverse relationship & 20 & 87.0 & 16 & 66.7 \\
\hline Absence of relationship & 1 & 4.3 & 4 & 16.7 \\
\hline Varies depending on another variable & 2 & 8.7 & 4 & 16.7 \\
\hline \multicolumn{5}{|c|}{ CRITERION FOR ESTABLISHING WEIGHT STATUS } \\
\hline IOTF $^{\mathrm{b}}$ cut-off points only & 50 & 100.0 & 36 & 100.0 \\
\hline Inverse relationship & 33 & 66.0 & 16 & 44.4 \\
\hline Absence of relationship & 11 & 22.0 & 8 & 22.2 \\
\hline Varies depending on another variable & 6 & 12.0 & 11 & 30.6 \\
\hline Direct relationship & 0 & 0.0 & 1 & 2.8 \\
\hline Other/s criteria/s & 84 & 100.0 & 54 & 100.0 \\
\hline Inverse relationship & 48 & 57.1 & 30 & 55.6 \\
\hline Absence of relationship & 14 & 16.7 & 10 & 18.5 \\
\hline Varies depending on another variable & 22 & 26.2 & 14 & 25.9 \\
\hline
\end{tabular}

${ }^{\mathrm{a}}$ Two or three of the above indicators of socioeconomic position were used bIOTF: International Obesity Task Force 
multivariable analyses, while in studies that used other criteria to define weight status, an inverse relationship was found in 57.1 and $55.6 \%$ of the bivariable and multivariable analyses, respectively.

\section{Discussion}

This review covered 158 studies undertaken in high income countries and reported from 1990 through 2013. More than half were published in the last 8 years. A total of $60.4 \%$ of papers that performed bivariable analyses observed an inverse relationship between weight status and family SEP, i.e. the measure of weight status registered the highest and lowest magnitudes in participants of low and high SEP, respectively. In contrast, no positive relationship was observed by the papers that performed a bivariable analysis. In the case of papers that conducted multivariable analyses, however, inverse and positive relationships were observed in 51.1 and $1.1 \%$ of cases, respectively.

\section{Trend in the association between socioeconomic position} and weigh status

On the basis of these results and the findings reported by the two earlier reviews published in 1989 and 2008 $[10,11]$, there is evidence of a change in the pattern of the relationship between SEP and childhood-adolescent weight status in developed countries. Specifically, there has been an increase in the proportion of studies reporting an inverse relationship because in the two earlier reviews, the percentage of papers that observed an inverse relationship stood at around $40 \%$. Sobal [10] observed a positive relationship in a quarter of the papers included. Accordingly, the presence of positive relationship in only one analysis in the studies included in Shrewsbury and Wardle's review [11] and in $1.1 \%$ of the multivariable analyses included in our current review, would support the almost disappearance of this relationship.

The increase in the proportion of studies registering an inverse relationship is highlighted when the results are observed by period: while none of the bivariable analyses published in the period 1990-1997 showed an inverse relationship, the number rose to $62.3 \%$ in analyses published in the period $1998-2005$ and to $64.0 \%$ in analyses published in the period 2006-2013. More than half of the bivariable analyses were published in the period 2006-2013, which may explain the higher percentage of studies reporting an inverse relationship in our review as compared with the two earlier reviews.

The increase of studies showing inverse relationship between SEP and child obesity reflects increased socioeconomic differences in the prevalence of overweight and obesity among adolescents [176]. We can not rule out that this increase may be due to increased economic inequality, since in the last thirty years there was an increase in income inequality in most rich countries [177]. However, it has also been observed an increase in socioeconomic differences in childhood obesity in countries where economic inequality has remained stable. Therefore we should not rule out the influence of other factors, such as the built environment related to physical activity and diet, on the observed results. For example, the availability of supermarkets and stores selling healthy foods has been reported to be lower in areas with lower income than in higher income areas [178], and as result the price of such foods is higher [179]. Likewise, it has been shown that there are fewer sports facilities in lower- than in higher-income areas, so that the probability of engaging in physical activity is also lower [178].

The implications of these findings are very important for health policy and for future research in this area. Although many political interventions warn of the importance of physical activity and healthy diet to prevent childhood obesity, the growing social disparities in child obesity observed in this review reveals the difficulties to reach and communicate health messages to families from lower socioeconomic groups. Some authors have suggested that higher socioeconomic groups tend to follow recommendations for health behaviours and respond more actively to health-related media messages than lower socioeconomic groups [79]. It is also possible that the built environment may create difficulties for the lower socioeconomic groups to adopt healthy behaviours. Future research in this area should be directed to identify why the lower socioeconomic groups do not follow healthy behaviours and evaluate interventions that can be implemented in order to reduce the prevalence of obesity in lower socioeconomic groups.

\section{Association varies depending on the measurement of outcome and exposure}

The relationship between SEP and adiposity differs according to measured or reported weight status. In most of the bivariable analyses based on reported weight status an inverse relationship was found, while this inverse relationship was only found in the half of the bivariable analyses based on measured weight status. The criterion chosen for establishing the weight status cut-off point also influence the type of relationship found, since a higher percentage of performed bivariable analyses found an inverse relationship when internationally accepted cut-off points were used. The same percentage of an inverse relationship was reported in bivariable analyses of studies from North America, Europe and rest of countries. In contrast, the percentage of studies reporting an inverse relationship varied, depending on the SEP indicator used: whereas $65.8 \%$ of studies that performed bivariable analyses using one of the parents' educational level displayed an inverse relationship, this percentage 
fell to $41.7 \%$ when the occupation of one of the parents was used to $37.5 \%$ when family household income was used. This finding is of great relevance when it comes to intervention strategies because it may possibly be factors related with parents' education rather than those related with occupation or household income that are accountable for the inverse relationship between SEP and childhood-adolescent weight status. An unexpected finding with the use of income was the difference in the percentage of inverse relationship in the case of bivariable or multivariable analyses: $37.5 \%$ versus $75.0 \%$. Probably this inconsistency is due to the number of bivariate and multivariate analysis performed only with family income is very low, 8 and 4 respectively. The increase in the number of studies will confirm or refute this finding.

Shrewsbury and Wardle's review [11] also found a high percentage of inverse relationship between parents' education and childhood-adolescent weight status (specifically, in $75 \%$ of studies that used this SEP indicator). The mechanisms whereby the different family SEP indicators influence children's and adolescents' weight status are probably different. For instance, parents' education is associated - to a larger extent than is either occupation or income - with a series of healthy lifestyles that influence children's and adolescents' weight status. In the adult population, a strong relationship is observed between education and the prevalence of healthy lifestyles [180-187]. Similarly, a number of studies have pointed that in homes where the parents have a higher educational level, the children are far more likely to follow a healthy diet and be more physically active [188-192]. Something that, at least in part, would be accounted by the influence of the parents' educational level on attitudes to health and by the exemplary nature of their lifestyles [193-196].

\section{The importance of other variables in the association}

Close on 1 of every 5 papers analyzed shows that the presence and/or type of relationship varies according to other variables, generally age, sex, race and year of study. In any given study, an inverse relationship was seen to appear in the latter years $[79,84,118]$ or in the oldest children $[94,105,113]$. In other cases, its magnitude increases with age $[25,116,153]$ or is greater in girls than in boys $[17,60,124,173]$ and sometimes this inverse relationship is observed in girls but is absent in boys [30, $32,44,72,78,83,137,147,153,154,173]$ or is observed only in white participants $[18,30-32,41,50,57,65]$. Similarly, the few positive relationships described affect social minorities $[18,39,50,103]$, i.e. immigrants in Germany, and African Americans and Mexicans in the USA.

In most of the studies, it is difficult to know why the researchers chose to disaggregate the data by social minorities. Perhaps this is due to the acquisition of patterns of risk behaviors. Such habits often first appear among the socioeconomically most privileged and/or indigenous population groups before subsequently appearing among the underprivileged and/or immigrant groups. This might account for the fact that, in developed countries, the inverse relationship between SEP and childhoodadolescent weight status is gradually growing and the positive relationship (peculiar to developing countries) is disappearing. It might also explain why the positive relationship in the case of developed countries is now essentially limited to minorities (certain ethnic groups and the immigrant population). Some authors noted that consumption of calorie-dense foods have increased in developing nations [197]. And it has been observed declines in habitual physical activity, and increases in sedentary behaviour. Traditional practices such as walking long distances, and habitual physical labour have been replaced by motorized transport, and sedentary activities, particularly in urban settings. These factors are now leading to increases in the occurrence of overweight/ obesity in developing countries.

Like Shrewsbury and Wardle [11], our review also shows that the inverse relationship displays a greater magnitude with the most severe forms of excess weight (i.e. obesity vs. overweight, or morbid obesity vs. obesity) $[47,61,64,87,88,90,91,97,99,101,102,135,159$, 171]. This may be due to a mathematical artifact. As a rule, the less frequent the health problem, the greater the magnitude of the relative differences in health among different population groups $[196,198]$. The rarer an outcome, the greater tends to be the relative socioeconomic difference in experiencing it. For example, a similar absolute difference in the prevalence of overweight and obesity in two groups - $30 \%$ vs $25 \%$ overweight, and $10 \%$ versus $5 \%$ in obesity- is a relative difference of 1.2 in the first case and 2.0 in the second.

\section{Strengths and limitations}

One aspect to be considered in this review - and indeed one which was also observed by Shrewsbury and Wardle [11] - is that most of the papers reviewed did not designate the relationship between SEP and childhoodadolescent weight status as their main study objective. This was either set a secondary goal, or the authors of the review deduced it from the results reported in the papers. This fact may have led to an underestimate of the number of papers with a statistically significant relationship, since the SEP measures in these cases do not tend to be defined in great detail. Furthermore, the bibliographic review conducted by Shrewsbury and Wardle [11] only used the PubMed database to search for papers. A strength of our review is its comprehensiveness, since the search was made in a number of databases. A further strength is that over half of the papers reviewed 
were published from 2006 through 2013, a period not covered by the earlier review.

As against an earlier review which only included objective measurements of weight status, ours also included measurements of weight status based on data reported by the study participants themselves, or by their parents or minders. Some authors have stated that reported weight-status data are reasonably valid for classifying children and adolescents as obese or non-obese in epidemiologic studies [199, 200]. Even so, errors of measurement and, by extension, an underestimation or an overestimation of the association cannot be excluded in such studies, if this information bias is different with respect to variables that reflected family SEP. Our findings suggest that a differential bias exists with respect to the SEP when the weight status is reported as almost $90 \%$ of the bivariable analyses found inverse relationship. Publication bias should therefore not be ruled out either. The influence of this bias was probably greater in this than in previous reviews, since our review included a time period during which there was considerable scientific consensus about the inverse relationship between SEP and childhood-adolescent obesity, thereby entailing greater difficulty in publishing results contrary to those expected.

Moreover, one should not lose sight of the limitations attributable to the restrictions imposed in the search, such as language and setting. Studies with languages other than English and Spanish have not been included in this review and have not been included studies from low-income countries. And one may wonder if the search terms in different databases may not have been sufficiently comprehensive. For example, in the PubMed search the term "education" was not included. Likewise, the search in other databases did not include terms like adolescent obesity or overweight or synonyms of social class.

According Petticrew and Roberts [12] one can run a simple check on the effectiveness of a search strategy by listing the key studies that one would expect to identify. These studies can be identified from existing literature reviews. In this sense, this search has found all studies that appear in the review of Shrewsbury and Wardle [11], whose search terms included, among others, education. Likewise, we verified that key articles from our personal database about socioeconomic position and obesity in adolescent appeared among articles that actually retrieved. Our search strategy was not very specific -proportion of retrieved studies that were relevant-, but the search terms and the wide range of databases used probably have enabled high levels of sensitivity to retrieve relevant articles.

In Europe the findings show one or two studies from some countries, such as the Czech Republic, Denmark or Switzerland. Nevertheless, inspection of the results in the countries where several studies have been carried out reveals that in most the observed relationship follows the general pattern, although the social and economic structure of the countries differs between them. However, it should be mentioned Greece, since majority of the studies from that country do not show relationship between SEP and childhood obesity, whereas in southern European countries like Italy or Spain, the observed relationship is mostly inverse.

\section{Conclusion}

The results of this review would seem to confirm the change in pattern which the two previous reviews had already hinted at, and points to the practical disappearance of the positive relationship between SEP and childhood-adolescent obesity in high income countries. Also, this review has shown that the SEP indicator that yields the highest proportion of inverse relationships is parents' education and that analyses based on the information of height and weight reported by parents obtain higher proportion of inverse relationships that analyses based on objective measurements.

\section{Additional file}

Additional file 1: Table S1. Studies that fulfilled the inclusion criteria. (DOC 460 kb)

\section{Abbreviations}

SEP: Socioeconomic position; WOK: Web of knowledge; Embase: Excerpta Medica Database; OECD: Organization for Economic Cooperation and Development; BMI: Body Mass Index; IOTF: International Obesity Task Force..

\section{Competing interests}

The authors declare that they have no competing interests.

\section{Authors' contributions}

LB and EM conceived and designed the study and led drafting of the paper. RA, RV and JMS collected, analysed and interpreted data. ER informed study design and execution, as well as interpreted data. All authors revised the drafted paper critically for important intellectual content and all authors gave final approval of the version to be published.

\section{Acknowledgements}

To Biblioteca Nacional de Ciencias de la Salud's documentalists and Mónica Ruiz. To Laura Laubach for her suggestions. This study was conducted thanks to support from the Research Project PI11/00784 "Socioeconomic context of residence area and overweight and obesity childhood" financed by the Ministry of Science and Innovation.

\section{Author details}

${ }^{1}$ Instituto de Salud Pública y Laboral de Navarra, Pamplona, Spain

${ }^{2}$ Department of Sociology, Universidad Pública de Navarra, Campus de Arrosadía, s/n, 31006 Pamplona, Spain. ${ }^{3}$ Department of Preventive Medicine and Public Health, Faculty of Medicine, Universidad Complutense de Madrid, Madrid, Spain. ${ }^{4}$ Instituto de Investigación Sanitaria del Hospital Clínico San Carlos (IdISSC), Madrid, Spain. ${ }^{5}$ CIBER Epidemiología y Salud Pública (CIBERESP), Madrid, Spain.

Received: 27 April 2015 Accepted: 4 September 2015

Published online: 21 September 2015 


\section{References}

1. Lakshman R, Elks CE, Ong KK. Childhood obesity. Circulation. 2012;126(14):1770-9.

2. Lobstein T, Frelut ML. Prevalence of overweight among children in Europe. Obes Rev. 2003:4(4):195-200.

3. Ogden CL, Yanovski SZ, Carroll MD, Flegal KM. The epidemiology of obesity. Gastroenterology. 2007:132(6):2087-102.

4. Wang Y, Beydoun MA. The obesity epidemic in the United States-gender, age, socioeconomic, racial/ethnic, and geographic characteristics: a systematic review and meta-regression analysis. Epidemiol Rev. 2007;29:6-28.

5. World Health Organization. Obesity: preventing and managing the global epidemic, WHO Technical Report Series; 894. Geneva: WHO; 2000.

6. Catenacci VA, Hill JO, Wyatt HR. The obesity epidemic. Clin Chest Med. 2009;30(3):415-44. vii.

7. Dietz WH. Health consequences of obesity in youth: childhood predictors of adult disease. Pediatrics. 1998;101(3 Pt 2):518-25.

8. Popkin BM, Duffey K, Gordon-Larsen P. Environmental influences on food choice, physical activity and energy balance. Physiol Behav. 2005;86:603-13.

9. Veblen T. Theory of the leisure class. Fairfield, NJ: Kelley; 1889.

10. Sobal J, Stunkard AJ. Socioeconomic status and obesity: a review of the literature. Psychol Bull. 1989;105(2):260-75.

11. Shrewsbury $V$, Wardle J. Socioeconomic status and adiposity in childhood: a systematic review of cross-sectional studies 1990-2005. Obesity (Silver Spring). 2008;16(2):275-84.

12. Petticrew M, Roberts $H$. Systematic Reviews in the Social Sciences A PRACTICAL GUIDE. Oxford: Oxford Blackwell Publishing; 2006

13. Riva M, Gauvin L, Barnett TA. Toward the next generation of research into small area effects on health: a synthesis of multilevel investigations published since July 1998. J Epidemiol Community Health. 2007;61(10):853-61.

14. Sanderson S, Tatt ID, Higgins JP. Tools for assessing quality and susceptibility to bias in observational studies in epidemiology: a systematic review and annotated bibliography. Int J Epidemiol. 2007:36(6):66-76.

15. Shamliyan $\mathrm{T}$, Kane RL, Dickinson S. A systematic review of tools used to assess the quality of observational studies that examine incidence or prevalence and risk factors for diseases. J Clin Epidemiol. 2010;63:1061-70.

16. Egger M, Schneider M, Davey SG. Spurious precision? Meta-analysis of observational studies. BMJ. 1998;316:140-4.

17. Ahn MK, Juon HS, Gittelsohn J. Association of race/ethnicity, socioeconomic status, acculturation, and environmental factors with risk of overweight among adolescents in California, 2003. Prev Chronic Dis. 2008;5(3):A75.

18. Alaimo K, Olson CM, Frongillo Jr EA. Low family income and food insufficiency in relation to overweight in US children: is there a paradox? Arch Pediatr Adolesc Med. 2001;155(10):1161-7.

19. Anderson PM, Butcher KF, Levine PB. Maternal employment and overweight children. J Health Econ. 2003;22(3):477-504.

20. Anderson SE, Whitaker RC. Household routines and obesity in US preschoolaged children. Pediatrics. 2010;125(3):420-8.

21. Baughcum AE, Chamberlin LA, Deeks CM, Powers SW, Whitaker RC. Maternal perceptions of overweight preschool children. Pediatrics. 2000;106(6):1380-6.

22. Butte NF. Impact of infant feeding practices on childhood obesity. J Nutr. 2009;139(2):412S-6S

23. Classen T, Hokayem C. Childhood influences on youth obesity. Econ Hum Biol. 2005:3(2):165-87.

24. Crooks DL. Child growth and nutritional status in a high-poverty community in eastern Kentucky. Am J Phys Anthropol. 1999;109(1):129-42.

25. Datar A, Sturm R. Physical education in elementary school and body mass index: evidence from the early childhood longitudinal study. Am J Public Health. 2004;94(9):1501-6.

26. Delva J, O'Malley PM, Johnston LD. Racial/ethnic and socioeconomic status differences in overweight and health-related behaviors among American students: national trends 1986-2003. J Adolesc Health. 2006;39(4):536-45

27. Delva J, Johnston LD, O'Malley PM. The epidemiology of overweight and related lifestyle behaviors: racial/ethnic and socioeconomic status differences among American youth. Am J Prev Med. 2007:33(4 Suppl):S178-86.

28. Gerald LB, Anderson A, Johnson GD, Hoff C, Trimm RF. Social class, social support and obesity risk in children. Child Care Health Dev. 1994:20(3):145-63.

29. Goodman E. The role of socioeconomic status gradients in explaining differences in US adolescents' health. Am J Public Health. 1999:89(10):1522-8.

30. Goodman E, Adler NE, Daniels SR, Morrison JA, Slap GB, Dolan LM. Impact of objective and subjective social status on obesity in a biracial cohort of adolescents. Obes Res. 2003;11(8):1018-26.
31. Goodman E, Slap GB, Huang B. The public health impact of socioeconomic status on adolescent depression and obesity. Am J Public Health. 2003;93(11):1844-50

32. Gordon-Larsen P, Adair LS, Popkin BM. The relationship of ethnicity, socioeconomic factors, and overweight in US adolescents. Obes Res 2003;11(1):121-9.

33. Haas JS, Lee LB, Kaplan CP, Sonneborn D, Phillips KA, Liang SY. The association of race, socioeconomic status, and health insurance status with the prevalence of overweight among children and adolescents. Am J Public Health. 2003:93(12):2105-10.

34. Hernandez-Valero MA, Wilkinson AV, Forman MR, Etzel CJ, Cao Y, Barcenas CH, et al. Maternal BMl and country of birth as indicators of childhood obesity in children of Mexican origin. Obesity (Silver Spring). 2007;15(10):2512-9.

35. Hofferth SL, Curtin S. Poverty, food programs, and childhood obesity. J Policy Anal Manage. 2005;24(4):703-26.

36. Li J, Hooker NH. Childhood obesity and schools: evidence from the national survey of children's health. J Sch Health. 2010;80(2):96-103.

37. Lutfiyya MN, Garcia R, Dankwa CM, Young T, Lipsky MS. Overweight and obese prevalence rates in African American and Hispanic children: an analysis of data from the 2003-2004 National Survey of Children's Health. J Am Board Fam Med. 2008;21(3):191-9.

38. McMurray RG, Harrell JS, Deng S, Bradley CB, Cox LM, Bangdiwala SI. The influence of physical activity, socioeconomic status, and ethnicity on the weight status of adolescents. Obes Res. 2000;8(2):130-9.

39. Miech RA, Kumanyika SK, Stettler N, Link BG, Phelan JC, Chang WW. Trends in the association of poverty with overweight among US adolescents, 1971-2004. JAMA. 2006:295(20):2385-93.

40. Neumark-Sztainer D, Story M, Hannan PJ, Croll J. Overweight status and eating patterns among adolescents: where do youths stand in comparison with the healthy people 2010 objectives? Am J Public Health. 2002;92(5):844-51

41. Patterson ML, Stern S, Crawford PB, McMahon RP, Similo SL, Schreiber GB, et al. Sociodemographic factors and obesity in preadolescent black and white girls: NHLBI's Growth and Health Study. J Natl Med Assoc. 1997:89(9):594-600.

42. Rhee KE, Lumeng JC, Appugliese DP, Kaciroti N, Bradley RH. Parenting styles and overweight status in first grade. Pediatrics. 2006;117(6):2047-54.

43. TK H i, Subramanian SV. School level contextual factors are associated with the weight status of adolescent males and females. Obesity (Silver Spring). 2008;16(6):1324-30.

44. Robinson TN, Kiernan M, Matheson DM, Haydel KF. Is parental control over children's eating associated with childhood obesity? Results from a population-based sample of third graders. Obes Res. 2001;9(5):306-12.

45. Rose D, Bodor JN. Household food insecurity and overweight status in young school children: results from the Early Childhood Longitudinal Study. Pediatrics. 2006;117(2):464-73.

46. Singh GK, Kogan MD, van Dyck PC. A multilevel analysis of state and regional disparities in childhood and adolescent obesity in the United States. J Community Health. 2008;33(2):90-102.

47. Skelton JA, Cook SR, Auinger P, Klein JD, Barlow SE. Prevalence and trends of severe obesity among US children and adolescents. Acad Pediatr. 2009;9(5):322-9.

48. Voorhees CC, Catellier DJ, Ashwood JS, Cohen DA, Rung A, Lytle L, et al. Neighborhood socioeconomic status and non school physical activity and body mass index in adolescent girls. J Phys Act Health. 2009;6(6):731-40.

49. Wang Y. Cross-national comparison of childhood obesity: the epidemic and the relationship between obesity and socioeconomic status. Int J Epidemiol. 2001;30(5):1129-36.

50. Wang $Y$, Zhang Q. Are American children and adolescents of low socioeconomic status at increased risk of obesity? Changes in the association between overweight and family income between 1971 and 2002. Am J Clin Nutr. 2006;84(4):707-16.

51. Whitaker RC, Phillips SM, Orzol SM, Burdette HL. The association between maltreatment and obesity among preschool children. Child Abuse Negl. 2007;31(11-12):1187-99.

52. Rossen LM, Schoendorf KC. Measuring health disparities: trends in racialethnic and socioeconomic disparities in obesity among 2- to 18-year old youth in the United States, 2001-2010. Ann Epidemiol. 2012;22(10):698-704.

53. Ogden $\mathrm{CL}$, Lamb MM, Carroll MD, Flegal KM. Obesity and socioeconomic status in children and adolescents: United States, 2005-2008. NCHS Data Brief. 2010;51:1-8 
54. Khullar D, Oreskovic NM, Perrin JM, Goodman E. Optimism and the socioeconomic status gradient in adolescent adiposity. J Adolesc Health. 2011;49(5):553-5.

55. Cardel M, Willig AL, Dulin-Keita A, Casazza K, Beasley TM, Fernandez JR. Parental feeding practices and socioeconomic status are associated with child adiposity in a multi-ethnic sample of children. Appetite. 2012;58(1):347-53.

56. Pardo-Crespo MR, Narla NP, Williams AR, Beebe TJ, Sloan J, Yawn BP, et al. Comparison of individual-level versus area-level socioeconomic measures in assessing health outcomes of children in Olmsted County, Minnesota. J Epidemiol Community Health. 2013;67(4):305-10.

57. Kimm SY, Obarzanek E, Barton BA, Aston CE, Similo SL, Morrison JA, et al. Race, socioeconomic status, and obesity in 9- to 10-year-old girls: the NHLBI Growth and Health Study. Ann Epidemiol. 1996;6(4):266-75.

58. Strauss RS, Knight J. Influence of the home environment on the development of obesity in children. Pediatrics. 1999;103(6):e85

59. Lumeng JC, Gannon K, Cabral HJ, Frank DA, Zuckerman B. Association between clinically meaningful behavior problems and overweight in children. Pediatrics. 2003;112(5):1138-45.

60. Singh GK, Kogan MD, van Dyck PC, Siahpush M. Racial/ethnic, socioeconomic, and behavioral determinants of childhood and adolescent obesity in the United States: analyzing independent and joint associations. Ann Epidemiol. 2008;18(9):682-95.

61. Singh GK, Kogan MD, Yu SM. Disparities in obesity and overweight prevalence among US immigrant children and adolescents by generational status. J Community Health. 2009;34(4):271-81.

62. Liu J, Bennett KJ, Harun N, Probst JC. Urban-rural differences in overweight status and physical inactivity among US children aged 10-17 years. J Rural Health. 2008;24(4):407-15.

63. Morgenstern M, Sargent JD, Hanewinkel R. Relation between socioeconomic status and body mass index: evidence of an indirect path via television use. Arch Pediatr Adolesc Med. 2009:163(8):731-8.

64. Singh GK, Siahpush M, Kogan MD. Rising social inequalities in US childhood obesity, 2003-2007. Ann Epidemiol. 2010;20(1):40-52.

65. Brophy S, Cooksey R, Gravenor MB, Mistry R, Thomas N, Lyons RA, et al. Risk factors for childhood obesity at age 5 : analysis of the millennium cohort study. BMC Public Health. 2009;9:467.

66. Duran-Tauleria E, Rona RJ, Chinn S. Factors associated with weight for height and skinfold thickness in British children. J Epidemiol Community Health. 1995:49(5):466-73.

67. Fletcher ES, Rugg-Gunn AJ, Matthews JN, Hackett A, Moynihan PJ, Mathers JC, et al. Changes over 20 years in macronutrient intake and body mass index in 11- to 12-year-old adolescents living in Northumberland. Br J Nutr. 2004;92(2):321-33.

68. Gray L, Leyland AH. Overweight status and psychological well-being in adolescent boys and girls: a multilevel analysis. Eur J Public Health. 2008;18(6):616-21.

69. Hawkins SS, Cole TJ, Law C. Maternal employment and early childhood overweight: findings from the UK Millennium Cohort Study. Int J Obes (Lond). 2008;32(1):30-8.

70. Hawkins SS, Cole TJ, Law C. An ecological systems approach to examining risk factors for early childhood overweight: findings from the UK Millennium Cohort Study. J Epidemiol Community Health. 2009;63(2):147-55.

71. Jebb SA, Rennie KL, Cole TJ. Prevalence of overweight and obesity among young people in Great Britain. Public Health Nutr. 2004;7(3):461-5.

72. Matijasevich A, Victora CG, Golding J, Barros FC, Menezes AM, Araujo CL, et al. Socioeconomic position and overweight among adolescents: data from birth cohort studies in Brazil and the UK. BMC Public Health. 2009;9:105.

73. Ness AR, Leary S, Reilly J, Wells J, Tobias J, Clark E, et al. The social patterning of fat and lean mass in a contemporary cohort of children. Int $J$ Pediatr Obes. 2006;1(1):59-61.

74. de Pinot MA, Power C, Li L. Changing influences on childhood obesity: a study of 2 generations of the 1958 British birth cohort. Am J Epidemiol. 2010;171(12):1289-98.

75. Saxena S, Ambler G, Cole TJ, Majeed A. Ethnic group differences in overweight and obese children and young people in England: cross sectional survey. Arch Dis Child. 2004;89(1):30-6.

76. Semmler C, Ashcroft J, van Jaarsveld CH, Carnell S, Wardle J. Development of overweight in children in relation to parental weight and socioeconomic status. Obesity (Silver Spring). 2009;17(4):814-20.
77. Stamatakis E, Primatesta P, Chinn S, Rona R, Falascheti E. Overweight and obesity trends from 1974 to 2003 in English children: what is the role of socioeconomic factors? Arch Dis Child. 2005;90(10):999-1004.

78. Stamatakis E, Zaninotto P, Falaschetti E, Mindell J, Head J. Time trends in childhood and adolescent obesity in England from 1995 to 2007 and projections of prevalence to 2015. J Epidemiol Community Health. 2010;64(2):167-74.

79. Stamatakis E, Wardle J, Cole TJ. Childhood obesity and overweight prevalence trends in England: evidence for growing socioeconomic disparities. Int J Obes (Lond). 2010;34(1):41-7.

80. Sweeting H, West P, Young R. Obesity among Scottish 15 year olds 19872006: prevalence and associations with socio-economic status, well-being and worries about weight. BMC Public Health. 2008;8:404.

81. Van Lenthe FJ, Boreham CA, Twisk JW, Strain JJ, Savage JM, Smith GD Socio-economic position and coronary heart disease risk factors in youth. Findings from the Young Hearts Project in Northern Ireland. Eur J Public Health. 2001;11(1):43-50.

82. Whincup PH, Cook DG, Papacosta O, Walker M. Childhood blood pressure, body build, and birthweight: geographical associations with cardiovascular mortality. J Epidemiol Community Health. 1992;46(4):396-402.

83. Howe LD, Tilling K, Galobardes B, Smith GD, Ness AR, Lawlor DA. Socioeconomic disparities in trajectories of adiposity across childhood. Int $J$ Pediatr Obes. 2011;6(2-2):e144-53.

84. Hargreaves DS, Djafari MA, Viner RM. Inequality trends in health and future health risk among English children and young people, 1999-2009. Arch Dis Child. 2013;98(11):850-5.

85. Howe LD, Galobardes B, Sattar N, Hingorani AD, Deanfield J, Ness AR, et al. Are there socioeconomic inequalities in cardiovascular risk factors in childhood, and are they mediated by adiposity? Findings from a prospective cohort study. Int J Obes (Lond). 2010;34(7):1149-59.

86. Whitaker KL, Jarvis MJ, Beeken RJ, Boniface D, Wardle J. Comparing maternal and paternal intergenerational transmission of obesity risk in a large population-based sample. Am J Clin Nutr. 2010;91(6):1560-7.

87. Apfelbacher CJ, Loerbroks A, Cairns J, Behrendt H, Ring J, Kramer U. Predictors of overweight and obesity in five to seven-year-old children in Germany: results from cross-sectional studies. BMC Public Health. 2008:8:171.

88. Bergmann KE, Bergmann RL, Von Kries R, Böhm O, Richter R, Dudenhausen JW, et al. Early determinants of childhood overweight and adiposity in a birth cohort study: role of breast-feeding. Int J Obes Relat Metab Disord. 2003;27(2):162-72

89. Danielzik S, Czerwinski-Mast M, Langnase K, Dilba B, Muller MJ. Parental overweight, socioeconomic status and high birth weight are the major determinants of overweight and obesity in 5-7 y-old children: baseline data of the Kiel Obesity Prevention Study (KOPS). Int J Obes Relat Metab Disord. 2004;28(11):1494-502.

90. Frye C, Heinrich J. Trends and predictors of overweight and obesity in East German children. Int J Obes Relat Metab Disord. 2003;27(8):963-9.

91. Kleiser C, Schaffrath RA, Mensink GB, Prinz-Langenohl R, Kurth BM. Potentia determinants of obesity among children and adolescents in Germany: results from the cross-sectional KiGGS Study. BMC Public Health. 2009;9:46.

92. Kromeyer-Hauschild K, Zellner K, Jaeger U, Hoyer H. Prevalence of overweight and obesity among school children in Jena (Germany). Int J Obes Relat Metab Disord. 1999;23(11):1143-50.

93. Langnase K, Mast M, Muller MJ. Social class differences in overweight of prepubertal children in northwest Germany. Int J Obes Relat Metab Disord. 2002;26(4):566-72.

94. Langnase K, Mast M, Danielzik S, Spethmann C, Muller MJ. Socioeconomic gradients in body weight of German children reverse direction between the ages of 2 and 6 years. J Nutr. 2003;133(3):789-96.

95. Mikolajczyk RT, Richter M. Associations of behavioural, psychosocial and socioeconomic factors with over- and underweight among German adolescents. Int J Public Health. 2008;53(4):214-20.

96. Muller MJ, Koertzinger I, Mast M, Langnase K, Grund A. Physical activity and diet in 5 to 7 years old children. Public Health Nutr. 1999;2(3A):443-4.

97. Nagel G, Wabitsch M, Galm C, Berg S, Brandstetter S, Fritz M, et al. Determinants of obesity in the Ulm Research on Metabolism, Exercise and Lifestyle in Children (URMEL-ICE). Eur J Pediatr. 2009;168(10):1259-67.

98. Plachta-Danielzik S, Landsberg B, Johannsen M, Lange D, Muller MJ. Determinants of the prevalence and incidence of overweight in children and adolescents. Public Health Nutr. 2010;13(11):1870-81. 
99. Toschke AM, Montgomery SM, Pfeiffer U, Von Kries R. Early intrauterine exposure to tobacco-inhaled products and obesity. Am J Epidemiol. 2003;158(11):1068-74.

100. Beyerlein A, Toschke AM, Schaffrath RA, Von KR. Risk factors for obesity: further evidence for stronger effects on overweight children and adolescents compared to normal-weight subjects. PLoS One. 2011;6(1):e15739.

101. Von Kries R, Koletzko B, Sauerwald T, von Mutius E, Barnert D, Grunert V, et al. Breast feeding and obesity: cross sectional study. BMJ. 1999;319(7203):147-50.

102. Von Kries R, Toschke AM, Koletzko B, Slikker Jr W. Maternal smoking during pregnancy and childhood obesity. Am J Epidemiol. 2002;156(10):954-61.

103. Will B, Zeeb H, Baune BT. Overweight and obesity at school entry among migrant and German children: a cross-sectional study. BMC Public Health. 2005;5:45.

104. Lamerz A, Kuepper-Nybelen J, Wehle C, Bruning N, Trost-Brinkhues G, Brenner $\mathrm{H}$, et al. Social class, parental education, and obesity prevalence in a study of six-year-old children in Germany. Int J Obes (Lond). 2005;29(4):373-80.

105. Hesketh K, Crawford D, Salmon J, Jackson M, Campbell K. Associations between family circumstance and weight status of Australian children. Int Pediatr Obes. 2007:2(2):86-96.

106. Mamun AA, Lawlor DA, O'Callaghan MJ, Williams GM, Najman JM. Positive maternal attitude to the family eating together decreases the risk of adolescent overweight. Obes Res. 2005;13(8):1422-30.

107. Sanigorski AM, Bell AC, Kremer PJ, Swinburn BA. High childhood obesity in an Australian population. Obesity (Silver Spring). 2007;15(8):1908-12.

108. Wang Z, Patterson CM, Hills AP. Association between overweight or obesity and household income and parental body mass index in Australian youth: analysis of the Australian National Nutrition Survey, 1995. Asia Pac J Clin Nutr. 2002;11(3):200-5.

109. Wake M, Hesketh K, Waters E. Television, computer use and body mass index in Australian primary school children. J Paediatr Child Health. 2003;39(2):130-4.

110. Jansen PW, Mensah FK, Nicholson JM, Wake M. Family and neighbourhood socioeconomic inequalities in childhood trajectories of BMI and overweight: longitudinal study of Australian children. PLoS One. 2013;8(7):e69676.

111. Gopinath B, Baur LA, Burlutsky G, Robaei D, Mitchell P. Socio-economic, familial and perinatal factors associated with obesity in Sydney schoolchildren. J Paediatr Child Health. 2012;48(1):44-51.

112. Taylor AW, Winefield H, Kettler L, Roberts R, Gill TK. A population study of 5 to 15 year olds: full time maternal employment not associated with high BMI. The importance of screen-based activity, reading for pleasure and sleep duration in children's BMI. Matern Child Health J. 2012;16(3):587-99.

113. Timperio A, Salmon J, Telford A, Crawford D. Perceptions of local neighbourhood environments and their relationship to childhood overweight and obesity. Int J Obes (Lond). 2005;29(2):170-5.

114. Wake M, Hardy P, Canterford L, Sawyer M, Carlin JB. Overweight, obesity and girth of Australian preschoolers: prevalence and socio-economic correlates. Int J Obes (Lond). 2007;31(7):1044-51.

115. Waters E, Ashbolt R, Gibbs L, Booth M, Magarey A, Gold L, et al. Double disadvantage: the influence of ethnicity over socioeconomic position on childhood overweight and obesity: findings from an inner urban population of primary school children. Int J Pediatr Obes. 2008;3(4):196-204.

116. Lioret S, Maire B, Volatier JL, Charles MA. Child overweight in France and its relationship with physical activity, sedentary behaviour and socioeconomic status. Eur J Clin Nutr. 2007;61(4):509-16.

117. Lioret S, Touvier M, Dubuisson C, Dufour A, Calamassi-Tran G, Lafay L, et al. Trends in child overweight rates and energy intake in France from 1999 to 2007: relationships with socioeconomic status. Obesity (Silver Spring). 2009;17(5):1092-100.

118. Romon M, Duhamel A, Collinet N, Weill J. Influence of social class on time trends in BMI distribution in 5-year-old French children from 1989 to 1999. Int J Obes (Lond). 2005;29(1):54-9.

119. Salanave B, Peneau S, Rolland-Cachera MF, Hercberg S, Castetbon K. Stabilization of overweight prevalence in French children between 2000 and 2007. Int J Pediatr Obes. 2009:4(2):66-72.

120. Thibault H, Carriere C, Langevin C, Kossi DE, Barberger-Gateau P, Maurice S. Prevalence and factors associated with overweight and obesity in French primary-school children. Public Health Nutr. 2013;16(2):193-201.

121. Chau N, Chau K, Mayet A, Baumann M, Legleye S, Falissard B. Self-reporting and measurement of body mass index in adolescents: refusals and validity, and the possible role of socioeconomic and health-related factors. BMC Public Health. 2013;13:815.

122. Klein-Platat C, Wagner A, Haan MC, Arveiler D, Schlienger JL, Simon C. Prevalence and sociodemographic determinants of overweight in young French adolescents. Diabetes Metab Res Rev. 2003;19(2):153-8.

123. Thibault H, Contrand B, Saubusse E, Baine M, Maurice-Tison S. Risk factors for overweight and obesity in French adolescents: physical activity, sedentary behavior and parental characteristics. Nutrition. 2010;26(2):192-200.

124. Bibiloni MM, Martinez E, Llull R, Juarez MD, Pons A, Tur JA. Prevalence and risk factors for obesity in Balearic Islands adolescents. Br J Nutr. 2010;103(1):99-106.

125. Moreno LA, Tomas C, Gonzalez-Gross M, Bueno G, Perez-Gonzalez JM, Bueno M. Micro-environmental and socio-demographic determinants of childhood obesity. Int J Obes Relat Metab Disord. 2004;28 Suppl 3:S16-20.

126. Serra ML, Ribas BL, Aranceta BJ, Perez RC, Saavedra SP, Pena QL. Childhood and adolescent obesity in Spain. Results of the enKid study (1998-2000). Med Clin (Barc). 2003;121(19):725-32.

127. Vicente-Rodriguez G, Rey-Lopez JP, Martin-Matillas M, Moreno LA, Wärnberg J, Redondo C, et al. Television watching, videogames, and excess of body fat in Spanish adolescents: the AVENA study. Nutrition. 2008;24(7-8):654-62.

128. Costa-Font J, Gil J. Intergenerational and socioeconomic gradients of child obesity. Soc Sci Med. 2013;93:29-37.

129. Navalpotro L, Regidor E, Ortega P, Martinez D, Villanueva R, Astasio P. Areabased socioeconomic environment, obesity risk behaviours, area facilities and childhood overweight and obesity: socioeconomic environment and childhood overweight. Prev Med. 2012;55(2):102-7.

130. Cantallops J, Ponseti FJ, Vidal J, Borràs PA, Palou P. Adolescence, physical inactivity and overweight: analysis based on socio-personal variables of the parents and the type of sport practiced by the children. Retos. Nuevas tendencias en Educación Física. Deporte y Recreación. 2012;21:5-8.

131. Dubois L, Girard M, Potvin KM. Breakfast eating and overweight in a preschool population: is there a link? Public Health Nutr. 2006;9(4):436-42.

132. Dubois L, Girard M. Early determinants of overweight at 4.5 years in a population-based longitudinal study. Int J Obes (Lond). 2006;30(4):610-7.

133. Willms JD, Tremblay MS, Katzmarzyk PT. Geographic and demographic variation in the prevalence of overweight Canadian children. Obes Res. 2003;11(5):668-73.

134. Simen-Kapeu A, Veugelers PJ. Socio-economic gradients in health behaviours and overweight among children in distinct economic settings. Can J Public Health. 2010;101 Suppl 3:S32-6.

135. Tremblay MS, Willms JD. Is the Canadian childhood obesity epidemic related to physical inactivity? Int J Obes Relat Metab Disord. 2003:27(9):1100-5.

136. Veugelers PJ, Fitzgerald AL. Prevalence of and risk factors for childhood overweight and obesity. CMAJ. 2005;173(6):607-13.

137. Ekelund U, Neovius M, Linne Y, Brage S, Wareham NJ, Rossner S. Associations between physical activity and fat mass in adolescents: the Stockholm Weight Development Study. Am J Clin Nutr. 2005;81(2):355-60.

138. Ekelund U, Ong K, Linne Y, Neovius M, Brage S, Dunger DB, et al. Upward weight percentile crossing in infancy and early childhood independently predicts fat mass in young adults: the Stockholm Weight Development Study (SWEDES). Am J Clin Nutr. 2006;83(2):324-30.

139. Huus K, Ludvigsson JF, Enskar K, Ludvigsson J. Risk factors in childhood obesity-findings from the All Babies In Southeast Sweden (ABIS) cohort. Acta Paediatr. 2007:96(9):1321-5.

140. Huus K, Ludvigsson JF, Enskar K, Ludvigsson J. Exclusive breastfeeding of Swedish children and its possible influence on the development of obesity: a prospective cohort study. BMC Pediatr. 2008:8:42.

141. Khanolkar AR, Byberg L, Koupil I. Parental influences on cardiovascular risk factors in Swedish children aged 5-14 years. Eur J Public Health. 2012;22(6):840-7

142. Panagiotakos DB, Antonogeorgos G, Papadimitriou A, Anthracopoulos MB, Papadopoulos M, Konstantinidou M, et al. Breakfast cereal is associated with a lower prevalence of obesity among 10-12-year-old children: the PANACEA study. Nutr Metab Cardiovasc Dis. 2008;18(9):606-12.

143. Yannakoulia M, Papanikolaou K, Hatzopoulou I, Efstathiou E, Papoutsakis C, Dedoussis GV. Association between family divorce and children's BMI and meal patterns: the GENDAI Study. Obesity (Silver Spring). 2008;16(6):1382-7

144. Moschonis G, Tanagra S, Vandorou A, Kyriakou AE, Dede V, Siatitsa PE, et al. Social, economic and demographic correlates of overweight and obesity in 
primary-school children: preliminary data from the Healthy Growth Study. Public Health Nutr. 2010;13(10A):1693-700.

145. Farajian P, Panagiotakos DB, Risvas G, Karasouli K, Bountziouka V, Voutzourakis $\mathrm{N}$, et al. Socio-economic and demographic determinants of childhood obesity prevalence in Greece: the GRECO (Greek Childhood Obesity) study. Public Health Nutr. 2013;16(2):240-7.

146. Cassimos D, Sidiropoulos H, Batzios S, Balodima V, Christoforidis A. Sociodemographic and dietary risk factors for excess weight in a greek pediatric population living in Kavala, Northern Greece. Nutr Clin Pract. 2011;26(2):186-91.

147. Boot AM, Bouquet J, de Ridder MA, Krenning EP, de Muinck Keizer-Schrama SM. Determinants of body composition measured by dual-energy X-ray absorptiometry in Dutch children and adolescents. Am J Clin Nutr. 1997;66(2):232-8.

148. Fredriks AM, van Buuren S, Wit JM, Verloove-Vanhorick SP. Body index measurements in 1996-7 compared with 1980. Arch Dis Child 2000;82(2):107-12.

149. Veldhuis L, Vogel I, van Rossem L, Renders CM, Hirasing RA, Mackenbach JP, et al. Influence of maternal and child lifestyle-related characteristics on the socioeconomic inequality in overweight and obesity among 5-year-old children; the "Be Active, Eat Right" Study. Int J Environ Res Public Health. 2013;10(6):2336-47.

150. Ruijsbroek A, Wijga AH, Kerkhof M, Koppelman GH, Smit HA, Droomers M. The development of socio-economic health differences in childhood: results of the Dutch longitudinal PIAMA birth cohort. BMC Public Health. 2011;11:225.

151. Van den Berg G, van Eijsden M, Vrijkotte TG, Gemke RJ. BMI may underestimate the socioeconomic gradient in true obesity. Pediatr Obes. 2013;8(3):e37-40.

152. De S, Dramaix M, Hennart P. Socioeconomic status and changes in body mass from 3 to 5 years. Arch Dis Child. 1998;78(5):477-8.

153. De S, Dramaix M, Hennart $P$. The influence of socioeconomic status on the incidence and evolution of obesity during early adolescence. Int J Obes Relat Metab Disord. 1998;22(3):268-74.

154. De S, Dramaix M, Hennart P. Social class and obesity in 12-year-old children in Brussels: influence of gender and ethnic origin. Eur J Pediatr. 1998;157(5):432-5.

155. Moens E, Braet C, Bosmans G, Rosseel Y. Unfavourable family characteristics and their associations with childhood obesity: a cross-sectional study. Eur Eat Disord Rev. 2009;17(4):315-23

156. Celi F, Bini V, De Giorgi G, Molinari D, Faraoni F, Di Stefano G, et al. Epidemiology of overweight and obesity among school children and adolescents in three provinces of central Italy, 1993-2001: study of potential influencing variables. Eur J Clin Nutr. 2003;57(9):1045-51.

157. De V, La Torre G, Langiano E, Berardi D, Ricciardi G. Overweight and Obesity among secondary school children in Central Italy. Eur J Epidemiol. 1999;15(7):649-54.

158. Giampietro O, Virgone E, Carneglia L, Griesi E, Calvi D, Matteucci E. Anthropometric indices of school children and familiar risk factors. Prev Med. 2002;35(5):492-8.

159. Gnavi R, Spagnoli TD, Galotto C, Pugliese E, Carta A, Cesari L. Socioeconomic status, overweight and obesity in prepuberal children: a study in an area of Northern Italy. Eur J Epidemiol. 2000;16(9):797-803.

160. Kautiainen S, Koivisto AM, Koivusilta L, Lintonen T, Virtanen SM, Rimpela A. Sociodemographic factors and a secular trend of adolescent overweight in Finland. Int J Pediatr Obes. 2009:4(4):360-70

161. Mikkila V, Lahti-Koski M, Pietinen P, Virtanen SM, Rimpela M. Associates of obesity and weight dissatisfaction among Finnish adolescents. Public Health Nutr. 2003:6(1):49-56.

162. Padez C, Mourao I, Moreira P, Rosado V. Long sleep duration and childhood overweight/obesity and body fat. Am J Hum Biol. 2009;21(3):371-6.

163. Nogueira H, Gama A, Mourao I, Marques V, Ferrao M, Padez C. The associations of SES, obesity, sport activity, and perceived neighborhood environments: is there a model of environmental injustice penalizing Portuguese children? Am J Hum Biol. 2013;25(3):434-6.

164. Morgen CS, Mortensen LH, Rasmussen M, Andersen AM, Sorensen TI, Due P. Parental socioeconomic position and development of overweight in adolescence: longitudinal study of Danish adolescents. BMC Public Health. 2010;10:520

165. Rasmussen M, Holstein BE, Due P. Tracking of overweight from mid-adolescence into adulthood: consistent patterns across socio-economic groups. Eur J Public Health. 2012;22(6):885-7.
166. Keane E, Layte R, Harrington J, Kearney PM, Perry IJ. Measured parental weight status and familial socio-economic status correlates with childhood overweight and obesity at age 9. PLoS One. 2012;7(8):e43503.

167. Griffin AC, Younger KM, Flynn MA. Assessment of obesity and fear of fatness among inner-city Dublin schoolchildren in a one-year follow-up study. Public Health Nutr. 2004;7(6):729-35.

168. Bammann K, Gwozdz W, Lanfer A, Barba G, De Henauw S, Eiben G, et al. Socioeconomic factors and childhood overweight in Europe: results from the multi-centre IDEFICS study. Pediatr Obes. 2013;8(1):1-12.

169. Toschke AM, Vignerova J, Lhotska L, Osancova K, Koletzko B, Von Kries R. Overweight and obesity in 6- to 14-year-old Czech children in 1991: protective effect of breast-feeding. J Pediatr. 2002;141(6):764-9.

170. Magnusson KT, Sveinsson T, Arngrimsson SA, Johannsson E. Predictors of fatness and physical fitness in nine-year-old Icelandic school children. Int J Pediatr Obes. 2008;3(4):217-25.

171. Huerta M, Bibi H, Haviv J, Scharf S, Gdalevich M. Parental smoking and education as determinants of overweight in Israeli children. Prev Chronic Dis. 2006;3(2):A48.

172. Lee HS, Duffey KJ, Kim Cl, Popkin BM. The relationship between family and child weight status by household structure in South Korea: 2007-2010. Nutr Diabetes. 2013;3:e73.

173. Lien N, Kumar BN, Holmboe-Ottesen G, Klepp Kl, Wandel M. Assessing social differences in overweight among 15- to 16-year-old ethnic Norwegians from Oslo by register data and adolescent self-reported measures of socioeconomic status. Int J Obes (Lond). 2007;31(1):30-8.

174. Buddeberg-Fischer B, Bernet R, Sieber M, Schmid J, Buddeberg C. Epidemiology of eating behaviour and weight distribution in 14- to 19-yearold Swiss students. Acta Psychiatr Scand. 1996;93(4):296-304.

175. Cole TJ, Bellizzi MC, Flegal KM, Dietz WH. Establishing a standard definition for child overweight and obesity worldwide: international survey. BMJ. 2000;320(7244):1240-3

176. Robertson A, Lobstein T, Knai C. Obesity and socio-economic groups in Europe: evidence review and implications for action. Brussels: European Commision; 2007.

177. OECD.An Overview of Growing Income Inequalities in OECD Countries: Main Findings. OECD 2011. http://www.oecd.org/els/soc/49499779.pdf (acessed June 21, 2015).

178. Boone-Heinonen J, Gordon-Larsen P. Obesogenic environments in youth Concepts and methods from a longitudinal national sample. Am J Prev Med. 2012:42:e37-46.

179. Macintyre S. Deprivation amplification revisited; or, is it always true that poorer places have poorer access to resources for healthy diets and physical activity? Int J Behav Nutr Phys Act. 2007:4:32.

180. Falk M, Anderson CD. Influence of age, gender, educational level and selfestimation of skin type on sun exposure habits and readiness to increase sun protection. Cancer Epidemiol. 2013;37(2):127-32.

181. Helmert U, Borgers D, Bammann K. Social determinants of smoking behavior in Germany: results of a 1995 micro-census. Soz Praventivmed. 2001;46(3):172-81

182. Kristiansen AL, Lande B, Overby NC, Andersen LF. Factors associated with exclusive breast-feeding and breast-feeding in Norway. Public Health Nutr. 2010;13(12):2087-96.

183. Lanting Cl, van Wouwe JP, van den Burg I, Segaar D, van der Pal-de Bruin KM. Smoking during pregnancy: trends between 2001 and 2010. Ned Tijdschr Geneeskd. 2012;156(46):A5092.

184. Morales-Asencio JM, Mancera-Romero J, Bernal-Lopez R, Martos-Cerezuela I, Baca-Osorio AJ, Moyano-Paris MT, et al. Educational inequalities and cardiovascular risk factors. A cross-sectional population-based study in southern Spain. Public Health Nurs. 2013;30(3):202-12.

185. Semyonov L, larocci G, Boccia A, La TG. Socioeconomic differences in tobacco smoking in Italy: is there an interaction between variables? Sci World J. 2012;2012:286472.

186. Sobal J. Obesity and socioeconomic status: a framework for examining relationships between physical and social variables. Med Anthropol. 1991;13(3):231-47.

187. Thompson FE, McNeel TS, Dowling EC, Midthune D, Morrissette M, Zeruto CA. Interrelationships of added sugars intake, socioeconomic status, and race/ethnicity in adults in the United States: National Health Interview Survey, 2005. J Am Diet Assoc. 2009;109(8):1376-83.

188. Fernandez-Alvira JM, te Velde SJ, De Bourdeaudhuij I, Bere E, Manios Y

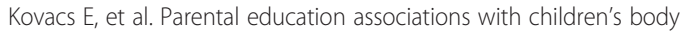


composition: mediation effects of energy balance-related behaviors within the ENERGY-project. Int J Behav Nutr Phys Act. 2013;10:80.

189. Hendricks K, Briefel R, Novak T, Ziegler P. Maternal and child characteristics associated with infant and toddler feeding practices. J Am Diet Assoc. 2006;106(1 Suppl 1):S135-48.

190. Kant AK, Graubard BI. Family income and education were related with 30year time trends in dietary and meal behaviors of American children and adolescents. J Nutr. 2013;143(5):690-700.

191. Kristiansen H, Juliusson PB, Eide GE, Roelants M, Bjerknes R. TV viewing and obesity among Norwegian children: the importance of parental education. Acta Paediatr. 2013;102(2):199-205.

192. Bozorgmehr E, Hajizamani A, Malek MT. Oral health behavior of parents as a predictor of oral health status of their children. ISRN Dent. 2013;2013:741783.

193. Can G, Topbas M, Oztuna F, Ozgun S, Can E, Yavuzyilmaz A. Factors contributing to regular smoking in adolescents in Turkey. J Sch Health. 2009;79(3):93-7.

194. Ozawa M, Washio M, Kiyohara C. Factors related to starting and continuing smoking among senior high school boys in Fukuoka, Japan. Asian Pac 」 Cancer Prev. 2008;9(2):239-45.

195. Rodenburg G, Oenema A, Kremers SP, van de Mheen D. Parental and child fruit consumption in the context of general parenting, parental education and ethnic background. Appetite. 2012;58(1):364-72.

196. Harper S, Lynch J. Methods for measuring cancer disparities: Using data relevant to Healthy People 2010. Cancer related objectives, NCl Cancer Surveillance Monograph Series, Number 6. Betsheda, MD: National Cancer Institute; 2005. NHI Publication No. 05-5777.

197. Muthuri SK, Francis CE, Wachira L-JM, LeBlanc AG, Sampson M, Onywera VO, et al. Evidence of an Overweight/Obesity Transition among School-Aged Children and Youth in Sub-Saharan Africa: A Systematic Review. PLOS ONE. 2014:9(3):e92846.

198. Scalan JP. Can we actually measure health disparities? Chance. 2006;19:47-51.

199. Garcia-Marcos L, Valverde-Molina J, Sanchez-Solis M, Soriano-Pérez MJ, Baeza-Alcaraz A, Martinez-Torres A, et al. Validity of parent-reported height and weight for defining obesity among asthmatic and nonasthmatic schoolchildren. Int Arch Allergy Immunol. 2006;139(2):139-45.

200. Sekine M, Yamagami T, Hamanishi S, Kagamimori S. Accuracy of the estimated prevalence of childhood obesity from height and weight values reported by parents: results of the Toyama Birth Cohort study. J Epidemiol. 2002;12(1):9-13.

\section{Submit your next manuscript to BioMed Central and take full advantage of:}

- Convenient online submission

- Thorough peer review

- No space constraints or color figure charges

- Immediate publication on acceptance

- Inclusion in PubMed, CAS, Scopus and Google Scholar

- Research which is freely available for redistribution 